\title{
Effect of adding humate to the ration of dairy cows on yield performance
}

\author{
Songül YÜCA ${ }^{1, a, \otimes}$, Mehmet GÜL ${ }^{2, b}$ \\ ${ }^{1}$ Ağrı İbrahim Çeçen University, Celal Oruç Animal Production School, Department of Animal Husbandry and Nutrition, Ağrı, \\ ${ }^{2}$ Atatürk University, Faculty of Veterinary Medicine, Department of Animal Nutrition and Nutritional Diseases, Erzurum, Turkey. \\ aORCID: 0000-0003-4507-9800; ' $O$ ORCID: 0000-0001-5477-1773

${ }^{\square}$ Corresponding author: syuca @ agri.edu.tr
Received date: 27.09.2019 - Accepted date: 16.06.2020

\begin{abstract}
The aim of this study is to investigate the effects of different levels of humate addition to colostrum quality, milk composition, somatic cell count, some blood metabolites and reproductive performance in the period from prepartum $40^{\text {th }}$ to postpartum $60^{\text {th }}$ day. In this study, dairy cows from prepartum $40^{\text {th }}$ to postpartum $60^{\text {th }}$ day were given humate additive which was according to dosed on dry matter consumption basis from (75 g, $150 \mathrm{~g})$. In the study, 26 Swiss Brown cows in the same care and feeding conditions were used in the second lactation. The feeds were weighed to determine the dry matter intake of the individual cows daily. Blood was collected from the vena jugularis at 40,30, 20 and 10 days before the estimated date of birth, at calving (day 0 ) and on days 5, 10, 20, 30, 45, and 60 after birth. Colostrum and milk samples were taken in the study. As a result of the study, it has been determined that the use of humate additives has no effect on body condition score, body weight, in milk non-fat milk solid, density, protein, lactose, freezing point, somatic cell count, in blood triglicerides, phosphorus, magnesium, albumin, glucose, blood urea nitrogen. It was found that with the addition of humate additive to the feed, colostrum specific gravity increased, prepartum and postpartum dry matter intake increased, milk yield and the fat percentage increased, serum non-esterified fatty acid and blood beta-hydroxybutyric acid levels decreased, and postpartum serum calcium level increased. It was concluded that $75 \mathrm{~g}$ of humate, which is determined based on dry matter consumption, can be added to the rations of the dairy cows at this dose and has positive effects on colostrum quality, milk yield, milk fat ratio, and negative energy balance.
\end{abstract}

Keywords: Dairy cow, humate, yield performance

\section{Süt ineklerinde rasyona humat ilavesinin verim performansı üzerine etkisi}

Özet: Bu çalışmanın amac1, doğum öncesi 40. günden doğum sonrası 60. güne kadar olan dönemde rasyona farklı seviyelerde humat ilavesinin kolostrum kalitesi, süt bileşimi, somatik hücre sayısı, bazı kan metabolitleri ve üreme performansı üzerine etkilerini araştırmaktır. Bu çalışmada, doğumdan önce 40. günden doğumdan sonraki 60 güne kadar olan dönemdeki süt ineklerine kuru madde tüketim esasına göre (75 g, $150 \mathrm{~g}$ ) belirlenen dozlarda humat katkı maddesi verilmiştir. Çalışmada, ikinci laktasyonda aynı bakım besleme şartlarında olan 26 İsviçre Esmeri inek kullanıld. Her bir ineğin kuru madde tüketimini günlük olarak belirlemek için yemler tartıld1. Doğumdan önceki 40, 30, 20 ve 10. beklenen doğum tarihinde, doğum anında (0. gün) ve doğumdan sonraki 5, 10, 20, 30, 45 ve 60. günlerde vena jugularis'ten kan alındı. Çalışmada kolostrum ve süt örnekleri alındı. Çalışma sonucunda humat katkı maddesi kullanımının vücut kondisyon skoru, canlı ağırlık, sütte; yağsız kuru madde, yoğunluk, protein, laktoz, donma noktası, somatik hücre sayısı, kanda; trigliserid, fosfor, magnezyum, albümin, glukoz, kan üre azotu üzerine etkisinin olmadığı tespit edilmiştir. Ancak kolostrum özgül ağıllı̆̆ının arttığı, prepartum ve postpartum kuru madde tüketiminin arttığı, süt veriminin ve sütteki yağ oranının arttığı, serum esterleşmemiş yağ asiti ve kan beta-hidroksi bütirik asit düzeylerinin azaldığı, postpartum serum kalsiyum düzeyinin arttığ bulunmuştur. Kuru madde tüketim esasına göre belirlenen $75 \mathrm{~g}$ humatın süt ineklerinin rasyonlarına bu dozda eklenebileceği, kolostrum kalitesi, süt verimi, sütte yağ oranı, negatif enerji dengesi üzerine olumlu etkilerinin olduğu sonucuna varılmıştır.

Anahtar sözcükler: Humat, süt ineği, verim performansı

\section{Introduction}

As a result of genetic and breeding studies carried out for years with the implementation of scientific advancements, high-quality products can be obtained from a small number of animals. The increased yield capacity of dairy cows made care feeding conditions difficult and increased their sensitivity to metabolic diseases. The most problematic period for dairy cows is the peripartum 
period, and feeding errors in this period adversely affect the health and productivity of the cow during the lactation period. In terms of pregnancy and lactation characteristics, the peripartum period can be categorized into the distant dry period (between day -60 and day -20 ), near dry period (between day -20 and birth), early postpartum period (between birth and day 14), and late postpartum period (between day 14 and day 60) (12).

Prebiotics, probiotics, enzymes, organic acids, plant extracts, and humates have been used as feed additives because they are environmentally friendly, they do not adversely affect on animal and human health, and they increase the quality and quantity of products obtained after the prohibition of the use of antibiotics as feed additives $(13,14)$.

Humates are composed of substances such as carbohydrates, amino acids and phenols, which are formed by decomposition and decomposition of plant and animal residues in the soil. Humates include humic, fulvic, ulmic acid and some microminerals originating from humus, and humates are organic substances capable of chelating with some metal ions and making electron transfer. Histopathological and histochemical studies have shown that humates are harmless on blood, cardiovascular system, endocrine system, and other important organ systems (1). Studies have also shown that humates have a protective effect against diseases, they can be used safely even in pregnant animals, and they have no embryotoxic effect $(1,11)$.

Studies on humates have found that they have a positive effect on average daily gain in calves and fattening cattle $(6,16,19)$; however, they have no effect on dry matter intake (DMI) in fattening cattle (4). Although they increase milk yield in Saanen goats, they do not change milk fat, non-fat milk solid, milk protein, lactose contents, and the total number of somatic cells and bacteria in milk $(7,8)$. Moreover, they increase dairy cow milk yield and ratio of milk fat to milk protein (20).

The aim of this study is to investigate the effects of different levels of humate addition to colostrum quality, milk composition, somatic cell count, some blood metabolites and reproductive performance in the period from prepartum $40^{\text {th }}$ to postpartum $60^{\text {th }}$ day

\section{Material and Methods}

The study included 26 Swiss Brown dairy cows in the second lactation with similar BCS; these cows were housed at Ağrı İbrahim Çeçen University Celal Oruç Animal Production School Education, Research and Application Farm. This study was approved by Atatürk University Animal Experiments Local Ethics Committee dated 18.09.2017 and numbered 36643897-000E.1700250736. The cows were randomly divided into three groups; nine of them as control, eight of them as consuming $75 \mathrm{~g}$ of humate daily, and nine of them consuming $150 \mathrm{~g}$ of humate daily. The humic acid material used for this study was purchased from the Natural Feed Company. The humate product (Bovifarm, Turkey) used for this study was dark black. The certified composition of humic acid produced by Bovifarm contains activated leonardite at a rate of $400.000 \mathrm{mg} / \mathrm{kg}$. The ration content used in the research is shown Table 1. The chemical composition of the feeds used in the research is shown in Table 2 and the chemical composition of total mix ration (TMR) is shown in Table 3. Animals were included in the experiment in the last 40 days before the estimated date of calving. The study groups were randomized to the control group, $75 \mathrm{~g}$ humate group, and $150 \mathrm{~g}$ humate group based on the randomized complete block design. In this study, two doses were studied. The dose of humate supplementation was determined according to dry matter consumption during dry period and lactation period. From the beginning of the study to the day of calving (-40-0) 75 $\mathrm{g}$ of humate additive, which was calculated based on dry matter consumption $(2 \%)$, was administered. After the calving $\left(0^{\text {th }}-60^{\text {th }}\right)$, depending on the increase in dry matter consumption (3.8\%) calculated $125 \mathrm{~g}$ humate additive was given. $75 \mathrm{~g}$ and $150 \mathrm{~g}$ were used from the beginning of the study to calving, $125 \mathrm{~g}$ and $250 \mathrm{~g}$ were used from the day of calving until the end of the study. Humate additive was

Table 1. Ingredient composition of diet.

\begin{tabular}{lc}
\hline Ingredient & Amount $(\mathbf{k g})$ \\
\hline Concentrate feed & 10 \\
Corn silage & 20 \\
Alfalfa hay & 2 \\
Fescue & 5 \\
\hline
\end{tabular}

Table 2. Chemical composition of dietary ingredients, $\%$.

\begin{tabular}{lcccccccc}
\hline Ingredient & DM & CP & CF & Fiber & Ash & Starch & ADF & NDF \\
\hline Concentrate feed & 89.91 & 19.35 & 2.58 & 9.80 & 7.04 & 23.91 & 31.21 & 16.48 \\
Fescue & 89.32 & 9.56 & 1.58 & 26.80 & 6.19 & - & 32.65 & 46.85 \\
Alfalfa hay & 87.35 & 13.46 & 2.27 & 22.60 & 8.26 & - & 32.98 & 41.21 \\
Corn Silage & 21.70 & 7.40 & 1.43 & 21.70 & 6.96 & - & 33.44 & 55.61 \\
\hline
\end{tabular}

DM: Dry matter; CP: Crude protein; CF: Crude fat; ADF: Acid detergent fibre; NDF: Neutral detergent fibre. 
Table 3. The chemical composition of the total mix ration (TMR), \%.

\begin{tabular}{|c|c|c|}
\hline Chemical composition & As feed & Dry matter \\
\hline Dry matter $\left(65^{\circ} \mathrm{C}\right)$ & 51.81 & \\
\hline Dry matter $\left(105^{\circ} \mathrm{C}\right)$ & 98.13 & 100.00 \\
\hline Ash & 4.43 & 8.55 \\
\hline Crude fat & 0.80 & 1.55 \\
\hline Crude protein & 6.60 & 12.74 \\
\hline Starch & 6.32 & 12.19 \\
\hline $\mathrm{NDF}$ & 25.52 & 49.27 \\
\hline $\mathrm{ADF}$ & 17.05 & 32.90 \\
\hline $\mathrm{ADL}$ & 4.34 & 8.37 \\
\hline NFC & 17.20 & 33.20 \\
\hline RUP $\% \mathrm{CP}^{1}$ & 39.00 & 39.00 \\
\hline $\mathrm{RDP} \% \mathrm{CP}^{1}$ & 61.00 & 61.00 \\
\hline RUP Digest ${ }^{1}$ & 62.00 & 62.00 \\
\hline $\mathrm{TDN}^{1}$ & 30.10 & 58.10 \\
\hline $\mathrm{N}$ Fraction $\mathrm{A}, \mathrm{CP}^{1}$ & 20.19 & 20.19 \\
\hline $\mathrm{N}$ Fraction $\mathrm{B}, \mathrm{CP}^{1}$ & 59.44 & 59.44 \\
\hline $\mathrm{N}$ Fraction $\mathrm{C}, \mathrm{CP}^{1}$ & 39.00 & 39.00 \\
\hline
\end{tabular}

NDF: Neutral detergent fibre; ADF: Acid detergent fibre; ADL: Acid detergent lignin; NFC: Non-fiber carbohydrate; RUP: Rumen undegradable protein; RDP: Rumen degradable protein; CP: Crude protein; TDN: Total digestible nutrient; ${ }^{1}$ : Obtained by calculation (17).

given to animals in the form of individual feed in individual paddocks. Humate additive was absorbed into $2 \mathrm{~kg}$ of silage and mixed into $5 \mathrm{~kg}$ of individual morning ration as a way for cows to consume the additive. The standard ration used in the study was prepared in TMR twice a day. The ration prepared to calculate the feed consumption of the animals in the experimental group was given by weighing individually in the morning and evening. The morning feeding was done at 8 am after milking, and the evening feeding was done at $6 \mathrm{pm}$. For monitoring feed consumption, the ration which was prepared at 8 in the morning and 6 in the evening was individually weighed using a weighing scale (TS500, TEM, Turkey) with a capacity of $25 \mathrm{~kg}$. The remaining feeds in front of the animals in the individual paddocks were collected and weighed. Morning ration was given to the animals who finished the silage mixed additive.

Postpartum vaginal discharge and odor controlled on day 5 and day 15, and morphological contraction of the uterus was checked by rectal examination. On postpartum day 20, the presence of corpus luteum (CL) in the ovary was detected by ultrasonography. Artificial insemination was performed on the postpartum day 60 using presynch+ovsynch synchronization method, and the study was completed in 100 days. In addition, pregnancy examination was performed by ultrasonography on the $35^{\text {th }}$ day after artificial insemination.

To determine the milk yield, milking was performed with Milkline's $2 \times 7$ herringbone model (Italy) milking system at 7 am and $5 \mathrm{pm}$, and milk volume was recorded at the end of each milking session using automatic lactometers. The body weights of the animals were measured on the days $-40,0,30$, and 60 using a weight scale (ST-1500H; Densi, Turkey). The body condition score (BCS) values of animals were averaged on the same day by two persons using Ferguson model 1-5 scoring inspection.

Blood samples were taken from vena jugularis at 40, 30,20 , and 10 days before the expected date of calving and on days $0,5,10,20,30,45$, and 60 after calving into two vials of non-anticoagulant $10 \mathrm{~mL}$ vacuum tubes after milking and before feeding in the morning. The sera were separated by centrifugation at $4000 \mathrm{rpm}$ for $10 \mathrm{~min}$ (NF800 , Nuve, Turkey) and stored at $-20^{\circ} \mathrm{C}$ until analysis. To determine the specific gravity of colostrum, colostrum samples were taken in a beaker at the first hour after the cow after calving, and the specific gravity was determined by the Kruuse Colostrometer. Milk samples of individually dairy cows in the morning on days 10, 20, 30, 45 , and 60 after birth were placed in $100 \mathrm{~mL}$ and $50 \mathrm{~mL}$ disposable sample containers. It were kept at $4{ }^{\circ} \mathrm{C}$ until analysis. The dry matter, crude protein, crude fat and ash contents of the diets were determined according to the AOAC (2). Neutral detergent fibre (NDF) and acid detergent fibre (ADF) were determined according to Van Soest (18). Dietary feed ingredients were analysed at Lalahan Ministry of Agriculture and Forestry International Livestock Research and Training Center Laboratory and chemical compositions were presented in Table 2. Rumen-degradable protein (RDP), rumenundegradable protein (RUP) and total digestible nutrient (TDN) values were calculated according to the methods specified in NRC (17). TMR analysis shown in Table 3 was performed in a special food and feed analysis laboratory (NutriLab, Turkey). Beta-hydroxybutyric acid (BHBA) analysis in blood samples was performed with blood ketone meter (Vet TD-4235, Taidoc, Taiwan), a BKetone measuring device, and test strips at the time of blood collection. Albumin (Alb), total protein (Tp), Triglicerides $(\mathrm{Tg})$, glucose, calcium $(\mathrm{Ca})$, magnesium $(\mathrm{Mg})$, and phosphorus (P) parameters of sera were estimated using Beckman Coulter AU5800 auto-analyzer (Beckman Coulter, USA) by the chemiluminescence immunoassay method at Atatürk University Research Hospital Biochemistry Laboratory. Non-esterified fatty acid (NEFA) from sera was read on Biotek ELISA reader using the bovine NEFA ELISA kit (SunRed brand catalog number 201-04-0186, China) at Atatürk University Faculty of Veterinary Science Department of 
Biochemistry Laboratory, and the results were shown in $\mu \mathrm{mol} / \mathrm{L}$ unit. The composition of milk samples was determined based on the ultrasound working principle using a milk analyzer (Milkotester brand Master Pro-P2 model, S/N: 22837, Bulgaria) at the Livestock Research and Application Center, Atatürk University. Somatic cell counting was performed using the Bentley model device (S/N: 7145, USA) using flow cytometry technique in the laboratory at Atatürk University Faculty of Veterinary Science Department of Obstetrics and Gynecology. On the postpartum days 5 and 15 , the uterus was checked for vaginal discharge and odor; in addition, the involution process was controlled by rectal examination on day 15 . On day 20, the presence of CL was checked by ultrasonography (Hasvet USG device, S/N: 838, China).

All data obtained from the research were analysed using SAS (2009 version). The model included humate level and time as fixed factors and cows within humate levels as random factor. The linear model included the main effects of humate level and time as well as humate level by time interaction, separately for the prepartum and postpartum periods. Differences among humate levels and time were attained by the Least Squared Differences option. Differences were indicated by superscripts $(\mathrm{P}<0.05)$.

\section{Results}

When the effect of humate addition on Body weight (BW) and Body condition score (BCS) was examined, no significant difference was found between the groups in both prepartum and postpartum periods as shown in Table
4. We examined DMI was prepartum and postpartum periods; Table 5 shows that the addition of humate significantly increased the DMI in both periods and milk yield in humate groups compared with the control group $(\mathrm{P}<0.05)$. It is shown in Table 6 that the addition of humate significantly increased the specific gravity of colostrum $(\mathrm{P}<0.05)$. Table 7 shows that when the effect of humate addition on milk composition and milk somatic cell count was examined, fat content, salt content, and conductivity in milk significantly increased in the treatment groups compared to the control group $(\mathrm{P}<0.05)$, and this addition had no influence on other milk composition components and somatic cell count. Table $8 \mathrm{a}$ and Table $8 \mathrm{~b}$ shows that when the effect of humate addition on some blood parameters was examined for prepartum and postpartum periods, humate addition significantly increased prepartum and postpartum albumin levels, postpartum $\mathrm{Ca}$ levels $(\mathrm{P}<0.05)$, significantly decreased prepartum and postpartum BHBA and NEFA levels $(\mathrm{P}<0.05)$, and had no influence on prepartum and postpartum $\mathrm{Tg}, \mathrm{P}, \mathrm{Mg}$, glucose, and BUN levels. Table 9 shows that humate addition to the ration did not significantly decrease vaginal odor on postpartum days 5 and 15; however, CL formation on day 20 was statistically significantly affected by humate addition.

Taken together, humate addition did not have a statistically significant impact on postpartum problems and pregnancy; however, shown in Table 10 uterine disorders numerically decreased and pregnancy ratio numerically increased with humate addition.

Table 4. The effect of humate addition to the ration on body weight and body condition score.

\begin{tabular}{|c|c|c|c|c|c|c|c|c|}
\hline \multirow{2}{*}{ Parameter } & \multicolumn{3}{|c|}{ Group } & \multirow{2}{*}{ Group } & \multirow{2}{*}{ Time } & \multirow{2}{*}{ Group*Time } & \multirow{2}{*}{ Linear } & \multirow{2}{*}{$\begin{array}{c}\text { Quadrat } \\
\text { c }\end{array}$} \\
\hline & $\mathbf{0}$ & H75 & H150 & & & & & \\
\hline \multicolumn{9}{|l|}{ Prepartum } \\
\hline BW (kg) & $625 \pm 10.1$ & $673 \pm 6.32$ & $645 \pm 5.02$ & 0.6373 & - & - & 0.8205 & 0.3660 \\
\hline BCS & $3.72 \pm 0.07$ & $3.68 \pm 0.05$ & $3.52 \pm 0.03$ & 0.6745 & - & - & 0.3962 & 0.8192 \\
\hline \multicolumn{9}{|l|}{ Postpartum } \\
\hline BW (kg) & $614 \pm 16.9$ & $613 \pm 11.47$ & $586 \pm 8.10$ & 0.2172 & 0.0233 & 0.9668 & 0.1557 & 0.2814 \\
\hline $\mathrm{BCS}$ & $3.32 \pm 0.10$ & $3.22 \pm 0.06$ & $3.11 \pm 0.06$ & 0.1830 & 0.0160 & 0.9408 & 0.0673 & 0.8771 \\
\hline
\end{tabular}

BW: Body weight; BCS: Body condition score; Group 0: Control group; Group H75: Adding 75 g of humate to the ration; Group H150: Adding $150 \mathrm{~g}$ of humate to the ration.

Table 5. The effect of humate addition to the ration on dry matter intake in the prepartum-postpartum period and milk yield

\begin{tabular}{|c|c|c|c|c|c|c|c|c|}
\hline \multirow{2}{*}{ Parameter } & \multicolumn{3}{|c|}{ Group } & \multirow{2}{*}{ Group } & \multirow{2}{*}{ Time } & \multirow{2}{*}{ Group*Time } & \multirow{2}{*}{ Linear } & \multirow{2}{*}{ Quadratic } \\
\hline & $\mathbf{0}$ & H75 & H150 & & & & & \\
\hline DMI pre $(\mathrm{kg})$ & $13.00 \pm 0.12^{\mathrm{c}}$ & $13.37 \pm 0.14^{\mathrm{b}}$ & $13.80 \pm 0.11^{\mathrm{a}}$ & 0.0001 & 0.0002 & 1.0000 & 0.0001 & 0.8738 \\
\hline DMI post $(\mathrm{kg})$ & $15.02 \pm 0.15^{\mathrm{b}}$ & $16.10 \pm 0.12^{\mathrm{a}}$ & $15.90 \pm 0.10^{\mathrm{a}}$ & 0.0001 & 0.0001 & 0.9986 & 0.0001 & 0.0001 \\
\hline MY (L) & $18.01 \pm 0.24^{\mathrm{c}}$ & $22.50 \pm 0.25^{\mathrm{a}}$ & $21.00 \pm 0.22^{\mathrm{b}}$ & 0.0001 & 0.0001 & 1.0000 & 0.0001 & 0.0001 \\
\hline
\end{tabular}

DMI pre: Dry matter intake in the prepartum period; DMI post: Dry matter intake in the postpartum period; MY: Milk yield; *: Different exponential letters on the same line indicate differences between groups $(\mathrm{P}<0.05)$; Group 0: Control group; Group H75: Adding $75 \mathrm{~g}$ of humate to the ration; Group H150: Adding $150 \mathrm{~g}$ of humate to the ration. 
Table 6. The effect of humate addition to the ration on specific gravity of colostrum.

\begin{tabular}{|c|c|c|c|c|c|c|}
\hline \multirow{2}{*}{ Parameter } & \multicolumn{3}{|c|}{ Group } & \multirow{2}{*}{ Group } & \multirow{2}{*}{ Linear } & \multirow{2}{*}{ Quadratic } \\
\hline & $\mathbf{0}$ & H75 & H150 & & & \\
\hline Colostrum specific gravity $(\mathrm{g} / \mathrm{mL})$ & $1041 \pm 3.61^{\mathrm{b}}$ & $1056 \pm 1.34^{\mathrm{a}}$ & $1058 \pm 0.81^{\mathrm{a}}$ & 0.0001 & 0.0001 & 0.0463 \\
\hline
\end{tabular}

*: Different exponential letters on the same line indicate differences between groups $(\mathrm{P}<0.05)$; Group 0: Control group; Group H75: Adding $75 \mathrm{~g}$ of humate to the ration; Group H150: Adding $150 \mathrm{~g}$ of humate to the ration.

Table 7. The effect of humate addition to the ration on milk composition and somatic cell count.

\begin{tabular}{|c|c|c|c|c|c|c|c|c|}
\hline \multirow{2}{*}{ Parameter } & \multicolumn{3}{|c|}{ Group } & \multirow{2}{*}{ Group } & \multirow{2}{*}{ Time } & \multirow{2}{*}{ Group*Time } & \multirow{2}{*}{ Linear } & \multirow{2}{*}{ Quadratic } \\
\hline & $\mathbf{0}$ & H75 & H150 & & & & & \\
\hline Fat (\%) & $3.31 \pm 0.09^{\mathrm{b}}$ & $3.71 \pm 0.13^{\mathrm{a}}$ & $3.72 \pm 0.15^{\mathrm{a}}$ & 0.0290 & 0.2120 & 0.7148 & 0.0253 & 0.1524 \\
\hline NFMS (\%) & $9.05 \pm 0.13$ & $9.19 \pm 0.06$ & $9.23 \pm 0.10$ & 0.4473 & 0.7970 & 0.8409 & 0.2314 & 0.6846 \\
\hline Density $\left(\mathrm{kg} / \mathrm{m}^{3}\right)$ & $30.60 \pm 0.48$ & $31.41 \pm 0.33$ & $31.13 \pm 0.38$ & 0.3783 & 0.7198 & 0.5994 & 0.3794 & 0.2816 \\
\hline Protein $(\%)$ & $3.24 \pm 0.05$ & $3.32 \pm 0.02$ & $3.32 \pm 0.04$ & 0.2464 & 0.7444 & 0.8267 & 0.1536 & 0.3861 \\
\hline Lactose (\%) & $4.90 \pm 0.07$ & $5.03 \pm 0.04$ & $5.02 \pm 0.05$ & 0.2231 & 0.8315 & 0.8313 & 0.1736 & 0.2863 \\
\hline Salt (\%) & $0.68 \pm 0.01^{\mathrm{b}}$ & $0.71 \pm 0.01^{\mathrm{a}}$ & $0.70 \pm 0.01^{\mathrm{ab}}$ & 0.0681 & 0.3561 & 0.8765 & 0.1256 & 0.0815 \\
\hline $\mathrm{FP}\left({ }^{\circ} \mathrm{C}\right)$ & $-0.587 \pm 0.01$ & $-0.592 \pm 0.00$ & $-0.594 \pm 0.01$ & 0.7657 & 0.1398 & 0.9377 & 0.4927 & 0.8079 \\
\hline $\begin{array}{l}\text { Conductivity } \\
(\mathrm{mS} / \mathrm{cm})\end{array}$ & $4.74 \pm 0.03^{b}$ & $4.79 \pm 0.03^{\mathrm{ab}}$ & $4.81 \pm 0.02^{\mathrm{a}}$ & 0.1084 & 0.4843 & 0.9402 & 0.0420 & 0.5944 \\
\hline LnscC & $10.42 \pm 0.18$ & $10.42 \pm 0.20$ & $10.46 \pm 0.20$ & 0.9954 & 0.0032 & 0.7839 & 0.9978 & 0.9238 \\
\hline
\end{tabular}

NFMS: Non-fat milk solid; SCC: Somatic cell count; FP: Freezing point; *: Different exponential letters on the same line indicate differences between groups $(\mathrm{P}<0.05)$; Group 0: Control group; Group H75: Adding $75 \mathrm{~g}$ of humate to the ration; Group H150: Adding $150 \mathrm{~g}$ of humate to the ration.

Table 8a. The effect of humate addition on blood parameters in the prepartum period.

\begin{tabular}{|c|c|c|c|c|c|c|c|c|}
\hline \multirow{2}{*}{ Parameter } & \multicolumn{3}{|c|}{ Group } & \multirow{2}{*}{ Group } & \multirow{2}{*}{ Time } & \multirow{2}{*}{ Group*Time } & \multirow{2}{*}{ Linear } & \multirow{2}{*}{ Quadratic } \\
\hline & $\mathbf{0}$ & H75 & H150 & & & & & \\
\hline $\mathrm{Tg}(\mathrm{mg} / \mathrm{dl})$ & $19.4 \pm 0.80$ & $20.81 \pm 0.92$ & $19.81 \pm 0.83$ & 0.5073 & 0.8126 & 0.9635 & 0.6955 & 0.2682 \\
\hline $\mathrm{Ca}(\mathrm{mg} / \mathrm{dl})$ & $9.03 \pm 0.06$ & $9.13 \pm 0.07$ & $8.95 \pm 0.06$ & 0.1625 & 0.8553 & 0.7935 & 0.5919 & 0.0704 \\
\hline $\mathrm{P}(\mathrm{mg} / \mathrm{dl})$ & $5.85 \pm 0.10$ & $5.93 \pm 0.10$ & $5.82 \pm 0.01$ & 0.6319 & 0.0454 & 0.8400 & 0.8508 & 0.3519 \\
\hline $\mathrm{Mg}(\mathrm{mg} / \mathrm{dl})$ & $2.44 \pm 0.03$ & $2.40 \pm 0.03$ & $2.44 \pm 0.0 .04$ & 0.5193 & 0.9711 & 0.1941 & 0.7245 & 0.2823 \\
\hline $\mathrm{Tp}(\mathrm{mg} / \mathrm{dl})$ & $7.58 \pm 0.08$ & $7.55 \pm 0.09$ & $7.57 \pm 0.09$ & 0.9444 & 0.0067 & 0.9325 & 0.8917 & 0.7598 \\
\hline $\mathrm{Alb}(\mathrm{mg} / \mathrm{dl})$ & $3.1 \pm 0.04^{\mathrm{a}}$ & $3.22 \pm 0.04^{\mathrm{a}}$ & $2.93 \pm 0.04^{\mathrm{b}}$ & 0.0001 & 0.7608 & 0.9975 & 0.0023 & 0.0001 \\
\hline Glucose (mg/dl) & $57.32 \pm 0.9$ & $57.98 \pm 1.28$ & $56.63 \pm 1.31$ & 0.7226 & 0.8824 & 0.8649 & 0.6775 & 0.4995 \\
\hline BUN (mg/dl) & $10.85 \pm 0.54$ & $11.26 \pm 0.50$ & $12.18 \pm 0.67$ & 0.2663 & 0.7737 & 0.9988 & 0.1161 & 0.7187 \\
\hline BHBA (mg/dl) & $9.19 \pm 0.46$ & $8.45 \pm 0.26$ & $8.42 \pm 0.36$ & 0.2940 & 0.2972 & 0.9595 & 0.1617 & 0.4280 \\
\hline $\mathrm{NEFA}(\mu \mathrm{mol} / \mathrm{L})$ & $25.35 \pm 1.90^{\mathrm{a}}$ & $20.17 \pm 2.35^{\mathrm{a}}$ & $14.72 \pm 2.29^{b}$ & 0.0010 & 0.5593 & 0.6621 & 0.0002 & 0.9501 \\
\hline
\end{tabular}

": Different exponential letters on the same line indicate differences between groups $(\mathrm{P}<0.05)$; Tg: Triglyceride; Ca: Calcium; P: Phosphorus; Mg: Magnesium; Tp: Total protein; Alb: Albumin; BUN: Blood urea nitrogen; BHBA: Beta-Hydroxybutyric acid; NEFA: Non-esterified fatty acid; Group 0: Control group; Group H75: Adding $75 \mathrm{~g}$ of humate to the ration; Group H150: Adding $150 \mathrm{~g}$ of humate to the ration.

Table 8b. The effect of humate addition on blood parameters in the postpartum period.

\begin{tabular}{|c|c|c|c|c|c|c|c|c|}
\hline \multirow{2}{*}{ Parameter } & \multicolumn{3}{|c|}{ Group } & \multirow{2}{*}{ Group } & \multirow{2}{*}{ Time } & \multirow{2}{*}{ Group*Time } & \multirow{2}{*}{ Linear } & \multirow{2}{*}{ Quadratic } \\
\hline & $\mathbf{0}$ & H75 & H150 & & & & & \\
\hline $\mathrm{Tg}(\mathrm{mg} / \mathrm{dl})$ & $5.47 \pm 0.30^{\mathrm{a}}$ & $4.55 \pm 0.28^{\mathrm{b}}$ & $4.85 \pm 0.25^{\mathrm{ab}}$ & 0.469 & 0.0001 & 0.9956 & 0.0972 & 0.0689 \\
\hline $\mathrm{Ca}(\mathrm{mg} / \mathrm{dl})$ & $8.21 \pm 0.06^{\mathrm{b}}$ & $8.66 \pm 0.08^{a}$ & $8.38 \pm 0.09^{b}$ & 0.0001 & 0.0001 & 0.0222 & 0.0418 & 0.0001 \\
\hline $\mathrm{P}(\mathrm{mg} / \mathrm{dl})$ & $4.81 \pm 0.12$ & $5.05 \pm 0.13$ & $5.04 \pm 0.14$ & 0.3311 & 0.0014 & 0.6750 & 0.1958 & 0.4772 \\
\hline $\mathrm{Mg}(\mathrm{mg} / \mathrm{dl})$ & $2.35 \pm 0.03$ & $2.41 \pm 0.04$ & $2.35 \pm 0.07$ & 0.5796 & 0.0001 & 0.1089 & 0.8199 & 0.3106 \\
\hline $\mathrm{Tp}(\mathrm{mg} / \mathrm{dl})$ & $7.54 \pm 0.14$ & $7.47 \pm 0.09$ & $7.31 \pm 0.10$ & 0.3037 & 0.0001 & 0.4795 & 0.1234 & 0.9910 \\
\hline $\mathrm{Alb}(\mathrm{mg} / \mathrm{dl})$ & $2.99 \pm 0.05^{\mathrm{b}}$ & $3.18 \pm 0.04^{\mathrm{a}}$ & $2.82 \pm 0.05^{\mathrm{c}}$ & 0.0001 & 0.2402 & 0.8238 & 0.0109 & 0.0001 \\
\hline Glucose (mg/dl) & $43.86 \pm 3.02$ & $42.96 \pm 2.44$ & $45.95 \pm 3.33$ & 0.6681 & 0.0001 & 0.9718 & 0.4250 & 0.6723 \\
\hline BUN (mg/dl) & $8.81 \pm 0.50$ & $9.86 \pm 0.57$ & $9.59 \pm 0.66$ & 0.3397 & 0.0067 & 0.5386 & 0.3418 & 0.2672 \\
\hline BHBA (mg/dl) & $9.27 \pm 0.61^{\mathrm{a}}$ & $7.47 \pm 0.35^{b}$ & $7.48 \pm 0.45^{b}$ & 0.0031 & 0.0001 & 0.5629 & 0.0019 & 0.1214 \\
\hline NEFA $(\mu \mathrm{mol} / \mathrm{L}$ & $31.45 \pm 1.89^{\mathrm{a}}$ & $14.96 \pm 1.35^{\mathrm{b}}$ & $16.1 \pm 1.25^{\mathrm{b}}$ & 0.0001 & 0.1444 & 0.0496 & 0.0001 & 0.0001 \\
\hline
\end{tabular}

*: Different exponential letters on the same line indicate differences between groups $(\mathrm{P}<0.05)$; Tg: Triglyceride; Ca: Calcium; P: Phosphorus; Mg: Magnesium; Tp: Total protein; Alb: Albumin; BUN: Blood urea nitrogen; BHBA: Beta-Hydroxybutyric acid; NEFA: Non-esterified fatty acid; Group 0: Control group; Group H75: Adding $75 \mathrm{~g}$ of humate to the ration; Group H150: Adding $150 \mathrm{~g}$ of humate to the ration. 
Table 9. The effect of humate addition on postpartum uterus and ovary.

\begin{tabular}{|c|c|c|c|c|c|}
\hline & \multicolumn{3}{|c|}{ Group } & \multirow{2}{*}{$\chi^{2}$} & \multirow{2}{*}{$P$ value } \\
\hline & $\mathbf{0}$ & H75 & H150 & & \\
\hline \multicolumn{6}{|l|}{ Day $5^{\text {th }}$} \\
\hline Smelling & 3 & 0 & 4 & \multirow{2}{*}{4.54} & \multirow{2}{*}{0.1000} \\
\hline Clean & 6 & 8 & 5 & & \\
\hline \multicolumn{6}{|l|}{ Day $15^{\text {th }}$} \\
\hline Smelling & 2 & 0 & 1 & \multirow{2}{*}{1.94} & \multirow{2}{*}{0.3789} \\
\hline Clean & 7 & 8 & 6 & & \\
\hline \multicolumn{6}{|l|}{ Day $20^{\text {th }}$} \\
\hline Corpus luteum + & 3 & 8 & 5 & \multirow{2}{*}{7.3965} & \multirow{2}{*}{0.0248} \\
\hline Corpus luteum - & 5 & 0 & 2 & & \\
\hline
\end{tabular}

Group 0: Control group; Group H75: Adding $75 \mathrm{~g}$ of humate to the ration; Group H150: Adding $150 \mathrm{~g}$ of humate to the ration.

Tablo 10. The effect of humate supplementation on postpartum problems and pregnancy.

\begin{tabular}{|c|c|c|c|c|c|}
\hline \multirow{2}{*}{ Problem } & \multicolumn{3}{|c|}{ Group } & \multirow{2}{*}{$\chi^{2}$} & \multirow{2}{*}{$P$ value } \\
\hline & $\mathbf{0}$ & H75 & H150 & & \\
\hline Endometritis & 1 & 0 & 0 & \multirow{6}{*}{14.4926} & \multirow{6}{*}{0.0698} \\
\hline Inactive ovarium & 2 & 0 & 0 & & \\
\hline Mastitis & 0 & 2 & 0 & & \\
\hline Retencio secundinarium & 2 & 0 & 4 & & \\
\hline Healty & 4 & 6 & 5 & & \\
\hline Artifical insemination & 8 & 8 & 7 & & \\
\hline Pregnancy + & 1 & 5 & 2 & \multirow{2}{*}{8.6133} & \multirow{2}{*}{0.0715} \\
\hline Pregnancy - & 7 & 3 & 5 & & \\
\hline
\end{tabular}

Group 0: Control group; Group H75: Adding $75 \mathrm{~g}$ of humate to the ration; Group H150: Adding $150 \mathrm{~g}$ of humate to the ration.

\section{Discussion and Conclusion}

Body condition score is related to milk yield, nutritional status, health status, and fertility and should thus be continuously monitored. It is desirable to perform both BCS and BW monitoring in herd management; however, it is a disadvantage that the equipment is insufficient in the facilities and live weight monitoring requires more labor force than the BCS. In this study, humate addition was not found to have a statistically significant effect on BCS and BW. McMurphy et al. (16) conducted a study where they added humate in the ration of different sexes; consequently, they reported that humate provided $13.4 \%$ more live weight gain in female calves and $21.2 \%$ in male calves compared to the control group calves. Teravita et al. (19) and Cusack et al. (6) reported that humic and fulvic acid improved the increase in daily live weight of cows. Tunç (21) reported that humate had no significant effect on the live weight. The reason for the results not matching may be because of different humate doses, ages, periods, and durations. DMI is an important parameter to be emphasized, particularly in the transition period in ruminants. In the studies, it was seen that humate addition increased DMI in prepartum and postpartum periods. According to Covington et al. (5) and McMurphy et al. (16) humate addition to the ration increased DMI in lambs and Holstein cows, respectively. It was reported that humate addition did not significantly affect DMI in fattening cattle by McMurphy et al. (15) in calves by Chirase et al. (4), and in Saanen goats by Degirmencioglu (7). These contradictory results may be due to the different amounts of dose and different periods.

Colostrum is a good source of immunoglobulin for calves to be born and its quality is very important. It was found that humate addition significantly increased the specific gravity of colostrum. On reviewing the literature, we found no study on the effect of humate addition on colostrum quality. The increase in specific gravity of colostrum is considered to be due to the immunomodulatory effect of humate.

In the present study, it was seen that humate addition increased milk yield and its fat content. Humate addition did not have a statistically significant impact on non-fat milk solid, milk protein, lactose content, density and freezing point. Degirmencioglu (7) reported that humate addition in Saanen goats increased milk yield but did not change fat content, non-fat dry matter content, protein content, lactose ratios, and somatic cell count in milk. Tomassen et al. (20) reported that humate addition 
increased milk yield and fat:protein ratio in milk and decreased somatic cell count by $50 \%$. Griban et al. (10) and Xiaowang et al. (23) reported that fulvic acid significantly reduced somatic cell count in intervention group cows compared to the control group ones. The reason for obtaining different results among the studies could be differences in individuals, sources, doses, durations of humate use, cattle breed and feed materials.

Blood parameters are an indicator of the metabolic profile, and the effects of humate addition can also be seen in the blood. Among the parameters examined, particularly $\mathrm{Ca}$, NEFA, and BHBA levels are very important during the transition period. In the present study, it was observed that humate addition significantly increased prepartum and postpartum albumin levels and postpartum $\mathrm{Ca}$ levels, and it significantly decreased prepartum and postpartum BHBA and NEFA levels. Further, it did not affect triglyceride, $\mathrm{P}, \mathrm{Mg}$, glucose, and BUN levels in prepartum or postpartum. Galip et al. (9) reported that humate addition in curly rams reduced serum albumin, glucose, $\mathrm{Ca}$, and $\mathrm{P}$ levels and increased total protein levels. Tunç and Yörük (22) reported that it did not change serum albumin, total protein, triglyceride, glucose, $\mathrm{Ca}$, and $\mathrm{P}$ levels in Red Karaman sheep. Budağ and Kara (3) reported that humate addition decreased serum total protein and increased serum BUN levels in Norduz sheep. It was reported that the humate addition did not change serum albumin, total protein, and $\mathrm{Ca}$ levels but increased $\mathrm{Mg}$ levels in bronze calves. Differences in the results among studies may be due to the different dose levels and different ages and races. In the review of literature, no study was found on the effects of humate addition on serum NEFA and BHBA; for this reason, they could not be sufficiently discussed. Humate use has been shown to decrease NEFA and BHBA levels before and after birth. Humate preparation may be thought to lead to relaxation in energy metabolism, especially in postpartum period. The low BHBA and NEFA values also led to an increase in dry matter consumption and an increase in milk yield in animals. This information supports each other.

In the present study, humate addition had no significant effect on vaginal odor on days 5 and 15 after birth, and it had a positive effect on CL formation on day 20. Humate addition has been shown to numerically reduce postnatal problems and numerically increase of pregnancy. In the review of literature, studies on the effects of humate on postnatal problems and pregnancy formation could not be found and therefore could not be sufficiently discussed.

According to our results, the addition of $75 \mathrm{~g}$ of humate had a positive effect on colostrum specific gravity, milk yield, milk composition, DMI, serum $\mathrm{Ca}$ and albumin levels, and serum NEFA and blood BHBA levels. Besides,
$75 \mathrm{~g}$ humate addition also had a positive effect on postpartum problems and pregnancy.

\section{Acknowledgement}

This study is produced from the first author's $\mathrm{PhD}$ thesis.

\section{Financial Support}

This study was supported by the Scientific Research Project Fund Atatürk University (Project number: TDK2017-6297).

\section{Ethical Statement}

This study was approved by Atatürk University Animal Experiments Local Ethics Committee dated 18.09.2017 and numbered 36643897-000-E.1700250736.

\section{Conflict of Interest}

The authors declared that there is no conflict of interest.

\section{References}

1. Anonymous (2017): Effect of humic acid on animals and humans an overview of literature and a review of current research. Available at http://www.humichealth.info/ effects.html (Accessed March 10, 2017).

2. Association of Official Analytical Chemists-AOAC (1990): Official Methods of Analysis. 15 ${ }^{\text {th }}$ ed. AOAC, Arlington, VA, USA.

3. Budağ C, Kara U (2016): The effect of use of humic acid in some blood parameters and rumen protozoa in Norduz lambs. Iğdır Univ J Inst Sci \& Tech, 6, 185-190.

4. Chirase NK, Greene LW, McCollum FT, et al (2000): Effect of bovipro on performance and serum metabolites concentrations of beef steers. Proc West Sec Amer Soc Anim Sci, 51, 415-418.

5. Covington BR, Ramsey WS, Greene LW, et al (1997): Effects of humate on feedlot performance and carcass characteristics in feedlot lambs. J Anim Sci, 75: 270.

6. Cusack PMV (2008): Effect of a dietary complex of humic and fulvic acids (FeedMAX15 ${ }^{T M}$ ) on the health and production of feedlot cattle destined for the Australian domestic market. Aust Vet J, 86, 46-49.

7. Degirmencioglu T (2012): Possibilities of using humic acid in diets for Saanen goats. Mlijekartsvo, 62, 278-283.

8. Degirmencioglu T, Ozbilgin S (2013): Effect of administration of humic acid on somatic cell count and total bacteria in Saanen goats. Inter J Vet Sci, 2, 151-154.

9. Galip N, Polat U, Biricik H (2010): Effects of supplemental humic acid on ruminal fermentation and blood variables in rams. Ital J Anim Sci, 9, 390-393.

10. Griban VG, Stepchenko LM, Zhorina LV (1988): The live weight gain and disease resistence of young cattle and poultry stock as influenced by physiologicalyactive peat preperation. 45-50. In: Proceedings of VIII Inter Peat Congress. Leningrad, Russia. 
11. Golbs S, Fuchs V, Kühnert M, et al (1982): Prenatal toxicologial testing of humic acids on laboratory rat. Arch Exp Veterinarmed, 36, 179-185.

12. Grummer RR (1995): Impact of changes in organic nutrient metabolism on feeding the transition dairy cow. $\mathrm{J}$ Anim Sci, 73, 2820-2813.

13. Karademir G, Karademir B (2003): Yem katkı maddesi olarak kullanılan biyoteknolojik ürünler. Lalahan Hay Araşt Enst Derg, 43, 61-74.

14. Kutlu HR, Serbester U (2014): Ruminant beslemede son gelişmeler. TURJAF, 2, 18-37.

15. McMurphy CP, Duff GC, Harris MA, et al (2009): Effects of humic/fulvic acid in beef cattle finishing diets on animal performance, ruminal ammonia and serum urea nitrogen concentration. J Appl Anim Res, 35, 97-100.

16. McMurphy CP, Duff GC, Sanders SR, et al (2011): Effects of supplementing humates on rumen fermentation in Holstein steers. S Afr J Anim Sci, 41, 134-140.

17. National Research Council-NRC (2001): Requirements of Dairy Cattle. Natl Acad Press, Washington DC.

18. Robertson JB, Van Soest PJ (1981): The Detergent System of Analysis. 123-158. In: WPT James, O Theander
(Eds), The Analysis of Dietary Fiber in Food. Marcel Dekker, New York.

19. Teravita TM (2018): Humates in poultry and stock farming. Available at http://www.teravita.com/humates/ chapter9.htm. (Accessed December 24, 2018).

20. Tomassen BPH, Faust RH (2018): The use of a processed humic acid product as a feed supplement in dairy production in the Netherlends, 339, In: Proceedings of The World Grows Organic International Scientific Conference, August, Basle, Switzerland.

21. Tunç MA (2012): Süt emme dönemindeki buză̆llarda humat ve probiyotiklerin performans, rumen fermentasyonu ve kan parametreleri üzerine etkisi. Doktora Tezi. Atatürk Üniversitesi Sağlık Bilimleri Enstitüsü, Erzurum.

22. Tunç MA, Yörük MA (2012): Humik asitlerin koyunlarda rumen ve kan parametreleri ile protozoon sayısı üzerine etkisi. Kafkas Üniv Vet Fak Derg, 18, 55-60.

23. Xiaowang X, Shaohaua S, Lixia H (2010): Study on the effect of biochemical fulvic acid on somatic cell count and milk performance of dairy cows. J Chin Dairy Cattle, 5, 17. 